\title{
LIMITATION OF ACTIONS IN TORT IN ALBERTA*
}

\author{
W. F. BOWKER $\$$
}

The purpose of this paper is to examine the law of Alberta on the subject of limitation of actions in tort; to see whether the law is uncertain or unfair; and if it is, to suggest changes in the statute law.

Until 1935 this province had no general Statute of Limitations.' For claims in tort, the English Limitations Act of 1623 applied. Thus, when an action was brought against the owner of a car who ran down a pedestrian, the Appellate Division in 1924 in Burd v. Macaulay ${ }^{2}$ had to decide whether the action was one of battery (four years) or an action upon the case (six years). The Appellate Division held that the claim was in battery and so was barred because the action was brought more than four years after the accident. Indeed this problem still haunts the courts of other provinces where the local statute is based on the Act of 1623.3

\section{Statute of Limitations}

However, this province in 1935 adopted a general Act' recommended by the Conference of Commissioners on Uniformity of Legislation. This was a great step forward. We are not concerned with those parts dealing with claims relating to land or trusts, but solely with Part I, which preseribes the periods for tort actions.

These are:

Section 5(1) ... (c) actions for defamation, whether lbbel or slander,

(i) within two years after publication of the libel or the speaking of the slanderous words, or

(i) where special damage is the gint of the action, within (d) actions for two years after the occurrence of such damage;

(i) trespass to the parson, anault battery, wounding or other injury to the person, whother arising from an unlawful act or from negllisonea;

(ii) false imprisonment

(iii) malicfous prosecution, or

(iv) eoduction,

within two years after the cause of action aroce;

(e) setions for

(i) trespass or injury to real property or chattels whether direct or indirect, and whether arising from an unlawful act or from negligence, or

(ii) the taking awray, conversion or detention of chattels,

within atx years after the cause of action arowe...

(j) any other action not in this Act or any other Act speciffeally provided for, within six years after the cause of action therein arose.

The important point to note is that actions in negligence for personal injury must be brought within two years, and actions for injury to real property or chattels within six years, after the cause of action arose.

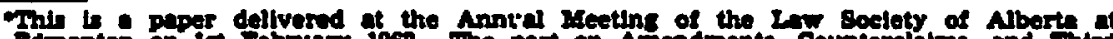

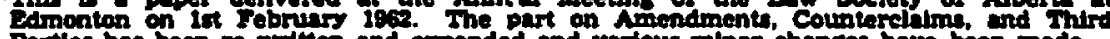

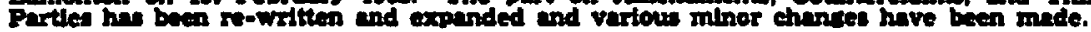

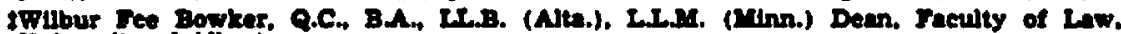
Untverity of Abert.

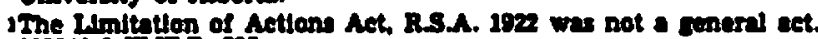

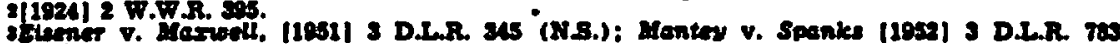
(B.C.).

Now the Indtation of Action Act, RBA. 1965 eap. $17 T$. 
Actions for assault, false imprisonment, malicious prosecution and seduction do not require examination. As for defamation, it should be noted that the Defamation Act of 1947 does away with the need to prove special damage in any case. In addition it has special provisions requiring notice before action against a newspaper or broadcasting station, and also requiring that action against them be brought within six months after the plaintiff learns of the defamation."

There are several miscellaneous torts not specifically mentioned in section 5, such as injurious falsehood, conspiracy, and inducing breach of contract. It would seem that these may be brought within six years under section $5(1)(j)$. The Supreme Court has held that an action for adultery is within this provision."

It is the action for negligence that raises most problems and this paper will deal particularly with that action. In connection with the application of section 5 , there are three questions that must be considered:

(1) when does the cause of action arise?

(2) when does the time expire?

(3) what is a cause of action in tort as distinct from one in contract?

Where the tort is complete when the wrongful act is done, as in assault or false imprisonment, it is obvious that the cause of action arises the moment the wrong is committed. However in the case of negligence, the gist of the action is the damage and not the wrongful act. In almost every case, there is some immediate damage, so for practical purposes the action is complete on the day the defendant commits his negligent act, and time begins to run from that day. It is hard to conceive of an ordinary accident in which no immediate damage occurs, but if there were, then time would run from the date when damage first arose. There are other types of case, however, where there is an interval of time between the wrongful act and the damage. For example, the defendant wrongfully removes the support from plaintiff's land in 1956 and the first damage, in the form of subsidence, occurs a year later. This is when time begins to run and successive actions may be brought for successive damage.' Another exceptional case is that of an employer who is negligent in permitting dust or fumes to enter the air so that after a time his employee's lungs are infected. In this case time begins to run from the damage, which may be long after the wrongful act. On the other hand the damage may accrue before the employee is aware of the fact. In that case time is running against him before he knows he has a cause of action." This is of course harsh on the plaintiff. However the problem is not likely to arise in Alberta because these claims come under the Workmen's Compensation Act.

(2) As to the expiration of the time for bringing action, the rule is that the last day is the anniversary of the day on which the cause of action arose. Thus, if a personal injury were sustained on January 31, 1960 the writ could be issued on January 31, 1962 and still be in time. One could argue that the last day is January 30 because in theory the

SRSA. I95S eap. 76. wees. 28-19.

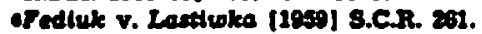

The leadins eave is Dartey Main Colliery v. Mitehath (28a6) I1 A.C. 187.

cartledoe v. Jopltin [1961] 3 All ER. 482. Compare 24 thale (s Ed.) parse 220 note (b). 
plaintiff could have issued his statement of claim on the day of the accident, and the Act says the action must be brought within two years. Thus if one were to count the day of the accident, the last day would be January 30 . However the day of the accident is excluded and thus the action may be brought on the anniversary:

(3) Turning now to the question whether an action is in contract or tort, this may be important in the case of personal injuries. The period is two years in tort and six in contract. The problem could arise where a person has a contract with another, (e.g. a guest at a hotel, a spectator at a performance, a passenger on a train, or an employee), and is injured through the negligence of that other. As a general rule be can base his claim on contract or tort, but where it becomes necessary to classify his action the cases say that his action sounds in tort because the obligation to take care arises under the common law and not under a provision in the contract. Thus he should bring his action within two years. The problem however has rarely arisen.10

In England, Parliament removed any doubt when it amended the Limitations Act in 1954 to provide that all action for personal injuries shall be brought within three years whether the duty arose under a statute or contract or independently of either."

One reason why there are comparatively few cases interpreting the tort provisions in the general Act (in addititon to the existence of the Workmen's Compensetion Act already mentioned) is the existence of special statutes which are not only considerable in number, but more important, very wide in their scope. On ordinary principles of construction, a special act prevails over a general one, and in Alberta this principle is set out in the Limitations Act itself.

It provides:

Section 5(2). Wothing in this section extends to an action where the time for bsinging the action is by atatute apecifically limited".

\section{Vehicles and Highway Traffic Act}

The first of these special provisions is section 131 of the Vehicles and Highway Traffic Act." It was enacted in 1941 and has its counterpart in Ontario and the other westem provinces.

"(1) No action shall be broight against a person for the recovery of damages ocessioned by a motor vehicie, after the expiration of twelve months from the the when the damages were sustatined".

(2) [lapse of the ta not a bar to a counterclaim or third party proceedings in respect of damages occasioned in the same accident]

(3) [repealed]

(4) [the court may extend the time a further twelve months where the aetion is brought against the registered owner and it later appears that ho was not the acturl owner]

Is there any good reason for a shorter period in the case of automobile

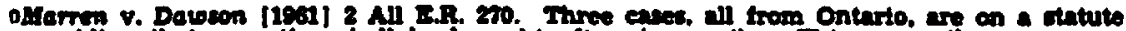

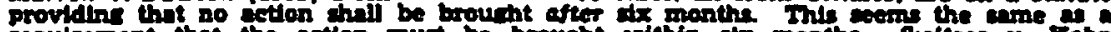

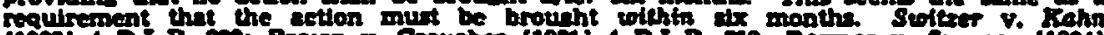

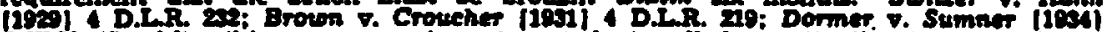

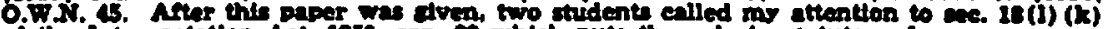
of the interpretation Act. 195s. enp. In which puts the rule in statutory form.

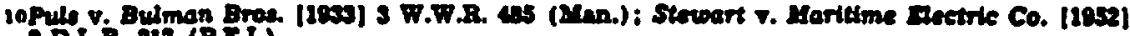
QD.L.R. 217 (P.E.I.).

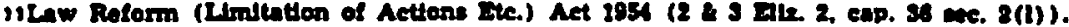

12R.S.A. 1956. eap. 258; am. 2959, cap. 98, we. 36. 
accidents than for negligence actions generally? I doubt it, but will leave the question here.

Three important questions arise under sec. 131:

(1) When does it apply?

(2) When are damages occasioned by a motor vehicle?

(3) Is a plaintiff under disability (from infancy or unsoundness of mind) bound by the section?

(1) This special limitation was first placed in Ontario's Highway Traffic Act in 1923. During the first few years the courts of Ontario tended to construe it narrowly. The Court of Appeal held in 1926's that it is confined to actions for the recovery of damages for a violation of the Act and does not apply to a common law action, e.g., where a passenger sued a tax company for injuries when the driver negligently closed the door on her hand. The same court held in 1928 that the section would not apply if the vehicle were not on the highway." In that case, the plaintiff on a sidewalk was struck by a bale of hay carried on a truck which was on a highway. The court held the section to apply.

The tendency to construe the section narrowly came to an end with Dufferin Paving Co. v. Anger. ${ }^{2 s}$ The words in the section should be given their natural and ordinary sense. Thus they apply to an action for damage done to a house by vibrations caused by trucks passing along the highway. The case also says by way of dictum that the section would apply where the plaintiff has a contract with the defendant, for example, where the plaintiff is a passenger in a taxicab. In 1959 an Ontario judge held that the section is not confined to accidents on a highway but applies to one on a farm. 30

In Alberta, the only reported case on this problem is Northern Alberta Dairy Pool v. Strong.. The defendant was a carrier who conveyed by truck a cargo of cheese owned by the plaintiff. A fire broke out en route thanks to a faulty carburetor, and then a second fire of unknown origin. The cargo was destroyed. Action was brought more than a year later. The defendant pleaded section 131. Milvain J. held that the action was against a common carrier on its common law liability and that the section does not apply. He thought it inconsistent that a common carrier using horses would be subject to a longer period than one using a motor vehicle, and distinguished Dufferin Peving. The point seems to be debatable. One can think of other cases where the time limitation does vary with the vehicle. Certainly if a carrier of passengers operates a stage coach as well as a motor bus, the periods are different where a passenger brings action for negligence.

(2) The second ground of decision in Strong brings us to the second question-when are damages "occasioned" by a motor vehicle? Mr. Justice Milvain held (and this may be the real ground of the decision) that the damage was not occasioned by the motor vehicle but by the fire, and its origin was unknown. With respect, this ground for the decision seems sound.

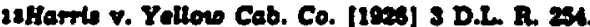

10Hughes $v$. Watkins liovej 2 D.L.R. 176.

is[1040] 8.C. . 174 .

ublere v. Neveru (1950) 0.W.N. 29

$17(1900)$ is W.T.R. 
There are a number of cases from other provinces on the meaning of "occasioned".1s Damages are not occasioned by a motor vehicle where its owner claims for damages to a vehicle against a person who had left a boulder on the road ${ }^{19}$ or who had allowed his horse to get on the road." The defendant cannot successfully invoke section 131. The damages were occasioned not by the car, but by the boulder or horse and were occasioned to the car. In several cases the owner of a car had lent it to another who damaged it by running it off the road. In an action by the owner against the driver for the damage to the car, the defendant cannot obtain the benefit of the section; ${ }^{21}$ nor can a bailee who has improperiy let someone else drive the car and that person is in a collision.22

What then is the position where the passenger in a car brings action against the driver who has been in collision with a train? In an early case, Riddell J.A. said that the damages were not occasioned by a motor vehicle at all, but by the locomotive which was enabled so to occasion them by the negligence of the driver.28 On the other hand the Saskatchewan Court of Appeal bas applied the section in similar circumstances. ${ }^{24}$ The later view seems preferable. Indeed where the car hits a cow, or train, it seems correct to say that if the owner of the cow or train were to counterclaim against the owner of the car, he could invoke the section as a defence to the counterclaim.

Sometimes it is said that "occasioned by a motor vehicle" means "occasioned by the driver of a motor vehicle". However, the driver cannot invoke this interpretation where the owner of the vehicle brings action against him for damage to it.

(3) The question of disability from infancy or unsoundness of mind is not difficult. Sec. 5 (2) of the Limitations Act, already quoted, says

Wothing in this section extends to an action where the time for bringing the action is specially limited by statute."

Section 8 says that a person entitled to bring an action for tort under section 5 (1) may do so within two years after the disability ceases. Since an action within section 131 of the Vehicles Act is outside section 5 (1) of the Iimitations Act, it seems clear that section 8 does not apply in favour of a plaintiff whose action is within section 131. Time runs against him immediately. The Court of Appeal of Saskatchewan has so held, ${ }^{28}$ and the Limitations Act and Vehicles Act are for present purposes the same in both provinces.

It might be noted that British Columbia's equivalent to sec. 131 has its own disability provision enabling an infant to bring action within a year of reaching twenty-one. ${ }^{20}$

\section{Municipal Acts}

In Canada, municipal statutes often give the municipality the benefit of a short period in actions for damages caused by breach of the statutory

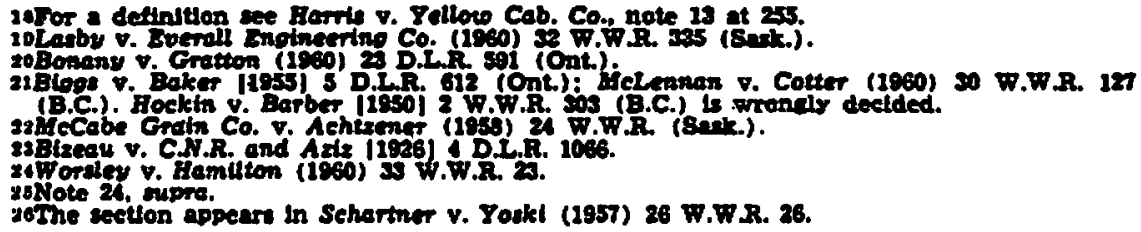


duty to repair highways. Our City Act imposes a one-year period and expressly extends its benefit to officials, employees and agents of the City. Notice of the claim must be given in sixty days (twenty-one in snow and ice cases), but notice is not required in the case of death of the person injured or where there is both reasonable excuse for failure to give it and no prejudice to the City.2:

There is a separate section, 695, for negligence claims." It is generally the same as the non-repair section. The main difference is that it does not specifically apply to an action against a servant or official of the City. Yet it says, "no action shall be brought" for injury or damage alleged to be caused by the City, its officials, employees or agents. This raises a nice question in statutory construction. A similar section has been applied in favour of a street car conductor who was joined with the City as defendent." However, in the recent case of Herdinic v. Calgary ${ }^{10}$ the Appellate Division held that a bus driver employed by the City and foined as a defendant is not within section 695 and therefore cannot involse the plaintiff's failure to give notice. The judgment points out that unless the section were confined to actions against the City, it would literally apply in favour of an employee who is negligent outside the course of his duties. ${ }^{203}$

The most startling provision in the City Act, and one which was the subject of two decisions in 1961, (sec. 453) will be discussed later in connection with the Public Officers Protection Act.

Under the Town and Village Act, the only special limitation provision is in connection with the duty to keep streets in repair. In that case notice must be given within one month, and action brought within a year after the cause of action arose." The provisions for excusing notice are lilse those in the City Act. The position of Municipal Districts is the same, save that the action for non-repair must be brought within six months. ${ }^{22}$ The Municipal Districts Act applies to counties. ${ }^{22}$ This means that actions in negligence, except for non-repair, are within the general limitation act or any other Act that may apply instead. In fact a municipality is a public authority," 80 where its own Act is silent it is entitled to the benefit of the special provisions of the Public Officers Protection Act." This Act can conveniently be examined now.

\section{Public Officers Protection Act}

\section{It provides:}

Section 2(1) Notwithstanding anything in any Aet or in the Consolidated Rules of the Supreme Court, where an action, prosecution or other proceoding is commenced in the Province against a perion

(a) for an act dome in pursuance or execution or intended execution of his duty as a public offecer, or

stR.8A. 1955, cap, 42, wee. 607-90.

atsoc. 6.

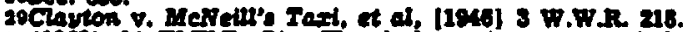

0 (106z) if $\mathbf{W . W . R}$. 74. The jud ment was roported after thls papar was presented. It

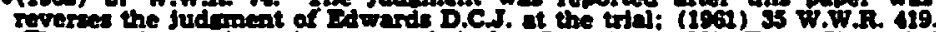

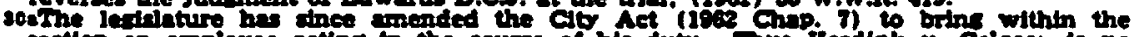
petton an emplosee aetins in the course of his duty. Thus birdink v. Caloary is no longer law.

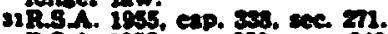

ans.A. 1035, esp; 200 . 200 . 240, 242.

incounty Aet, RSA. iess. eap. GA, iec. 25.

INBradford v. Arvere [1016] A.C. 20.

isRs $A$. 1955, eap. 202. 
(b) in respect of an alleged neglect or defoult in the exceution of his duty or authority as a public offices,

the provisions of this Aet apply.

(2) An action, prosecution or proceeding mentioned in subsection (1), does not lie and shall not be instituted

(a) unless it is commenced within six months after the act, nogleat or default complained of, or

(b) where there is a continuance or injury or damage, within six monthe after the ceasing thereof.

(7) This Act does not affect any proceeding by a department of the Government against an authority or officer or a city, town, village, county or municipal district.

This Act is based on the English Public Authorities Protection Act of 1893 (repealed in 1954) and is found in a number of the common law provinces. It does not define public authority or public officer and this alone creates grave doubts as to whom it applies. In Alberta a city policeman'se and a member of the R.C.M.P.27 have been held to be public officers. In Halpin v. Reginam"s a truck driver for a Dominion experimental farm was denied the benefit of the Act. There may however be an implication in the judgment that he was a public officer, for the emphasis is on the fact that he was not engaged in the execution of a public duty when he committed the negligent act. Elsewbere, school boards and teachers, public hospitals and a variety of municipal and Crown officials and servants, even unto a private in the army, whose duties were to drive a truck," all have been held to be within the Act. Our Appellate Division has held that a man working with his tractor on a highway under the supervision of a district engineer of the Department of Public Works is not a public officer. ${ }^{+\infty}$ This case suggests that the Act is confined to public officers who exercise a degree of responsibility or control, though in the case of the army private, the Inglish Court of Appeal rejected this test.

A question that has not arisen in Alberta relates to the limitation in an action against the Crown under the Proceedings Against the Crown Act" enacted in 1959. That Act specifies no period. In my opinion, the Public Officers Protection Act applies."2

Two recent cases from Calgary disclose a curious situation mentioned earlier in connection with the City Act. Part VII of that Act is headed "Public Utilities" and section 438 makes it clear that the City is liable for damage caused by the negligent operation of its utilities. In the first case, Harvey v. Calgary," the plaintiff was injured when he touched a live electric wire belonging to the City's electric distribution system. Fis action was commenced within a year, but after six months. The City involed section 453 which is near the end of Part VII and reads:

The Clty, it officers, agents and servanta, shall be deemed to have the like

sokellie $\nabla$. Caloers (1951) 1 T.W.R. (K.S.) 01

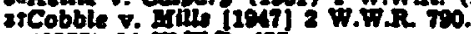

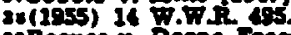

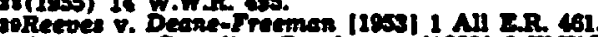

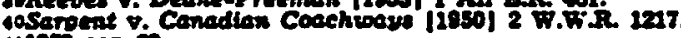

$110 \mathrm{sos}$ en.

trithe Crown Proceedinge Act, IA47 (Imp.) we. 30 (2) eald that "nothine in this Aet shall

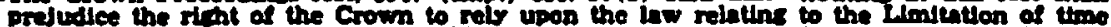

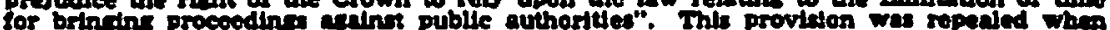

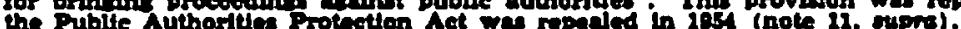

as (1001) 35 W.V.R. 68 . 
protection in the exercise of its and their respective offices and the execution of lts and their duties as public officers have under the laws of the Province."

From this the City argued that the Public Officers Protection Act applies to actions relating to utilities. Milvain J. found for the City on the merits, but went on to express the opinion that section 453 brings the Public Officers Protection Act into play where the action relates to utilities.

In the later case of McGinn v. Calgary, decided by Cairns, J. on December 29, 1961," the plaintiff was injured by a city bus and the action like Harvey's was brought within the year but after six months. His Lordship beld that the limitation provisions in the City Act provide a complete code for negligence actions and that sec. 453 does not override them.

Time does not permit an analysis of the two judgments, but if the view of Milvain $\mathrm{J}$. is correct, sec. $\mathbf{4 5 3}$ should be repealed forthwith.

The foregoing account shows that it is very hard to determine who is a public officer. In connection with school boards and teachers, it is probable that plaintiffs and perhaps school authorities as well overlooked the fact that boards and teachers are public authorities, ${ }^{\text {ts }}$ and this may be the reason why the School Act was amended in $\mathbf{1 9 5 2}$ to provide that the board, officers and teachers "shall be deemed" to be public officers." ${ }^{\circ}$

Even when a defendant is found to be a public officer he is entitled to the protection of the Act only for an act done in pursuance of his duty as a public officer or in respect of neglect in the execution of his duty or authority as a public officer. If the act is not done in pursuance of a duty, but merely in excecution of an incidental power then he does not have the benefit of the Act."

Sometimes the action is not for negligence but for some other tort such as assault, or false imprisonment. In these cases the courts refuse to give the defendant the benefit of statutes like our Protection Act if the defendant's act is completely outside his duties or is done in bad faith."

Another feature of the Act is the short period for bringing actionsix months. In no other important limitation provision in Alberta is the period less than a year.

Finally, section 2 says, "Notwithstanding anything in any Act or in the Consolidated Rules of the Supreme Court . . . the provisions of this Act apply." Being a special Act, it would clearly prevail over the Limitations Act even without the "notwithstanding" clause, but serious problems are created when there is another special statute such as the Vehicles Act, and others I shall mention later.

(1968) $\pi$ T.W.R. 34.

4sGrtftith v. Smlth [2911] A.C. 170.

OR.B.A. 2955. cap. 207 . we. 49.

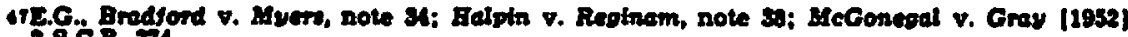
2 8.C.R. 374

4Chaput Y. Romatn [10s5] 8.C.R. as4; Lamb v. Benote [1059] 8.C.R. 221; Ronearelli v.

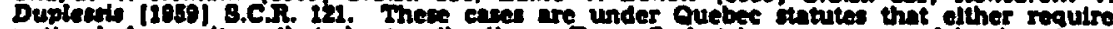

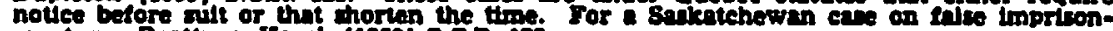
ment, wee Beatty v. Korale [IOSA] E.C.R. IT7. 
Fatal Accidents Act

The next statute with its own special period is the Fatal Accidents Act which allows one year from death."

The first situation that requires consideration is this. The victim of the wrongdoer's negligence dies before his action in negligence had expired under the applicable statute which would be either the Limitations Act, the Vehicles \& Highway Traffic Act, a municipal Act, the Public Officers' Protection Act or some other special act. Now if the action under the Fatal Accidents Act is brought before that period has expired, no possible question arises. However it may expire within a year or even a week of death. Does this mean that the defendant can raise as a defence the original statute so that the plaintiff in the Fatal Accidents Act is barred after the period prescribed by the original statute has passed even though the action is brought within a year of death?

In general, the answer is no. As long as the victim's action was not barred when he died, his dependants have the year given them by the Fatal Accidents Act. They had no cause of action prior to death and it would be unreasonable to say that time was running against them before their cause of action arose. The Privy Council so held in Gentile v. B.C. Electric Railway.

One might argue that a provision such as section 131 of the Vehicles Act, which is very wide in its terms, leads to the opposite result, but I submit it does not. The only Act that might operate as a bar after its original period is gone is the Public Officers Protection Act for it applies "notwithstanding any other Act" and the six months' period runs from the wrongful act. If this is the effect then the one-year period of the Fatal Accidents Act is seriously curtailed, and indeed it is barred from the beginning where the victim survived over six months.

Next we shall consider the position where the victim's cause of action was barred before he died. In that event the clear inference from Gentile is that the Fatal Accidents action is out of time. The Act says action may be brought when death "has been caused by such wrongful act, neglect or default as would if death had not ensued, have entitled the injured party to maintain an action and recover damages in respect thereof". It has long been settled that the dependant's action fails if the deceased himself had obtained judgment or given a valid release, and the same applies where his action was barred before be died. Anglin J. stated in B.C. Electric Ry. Co. v. Turner-si

"I find no satisfactory ground of distribution between the extinguishment of the cause of action by the injured man by an accord and satisfaction, evidenced by a roloase, and tis extinguishment by the rocovery of a judgment upon it or the expiry of a period of limitation".

Trustee Act

At common law an action in tort (with an exception not relevant here) came to an end with the death of either victim or tortfeasor. In 1886 Ontario abrogated this rule by an amendment to the Trustee Act

40R.8.A, 1955, cap. 181, wec, 5.

so[1916] A.C.. 1034; also Vern v. Tedesce [1028] 2 R.B. 227.

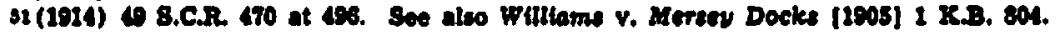


that provides for survival of actions in tort. Our Trustee Ordinance of $1903^{\text {iz }}$ follows the Ontario Act. Until the House of Lords decision in Rose v. Fordss these survival provisions were rarely invoked. Since then they have been used by the representative of a victim mainly in connection with damages for loss of expectation of life-a claim incidentally that is no longer admitted in most provinces.

Fngland followed Ontario's lead in 1934 and now all the common law provinces have provision for survival of actions in tort, most of them on either the Ontario or English model, but with a variety of limitation provisions. At present the Conference of Commissioners on Uniformity of Legislation is in the process of preparing a model survival Act.

In the meantime, section 32 of our Trustee Act says that where the victim dies, action by his estate against the wrongdoer must be brought within a year of his death; and section 33 says that where the wrongdoer dies, the victim's action against his estate must be brought within a year of his death.

One point on which I have found no direct authority, but which seems clear, is that the action does not survive if the claim was barred under the applicable limitation statute at the time of the death, whether it be of viction or wrongdoer.".

The question that has caused difficulty is whether the period in the Trustee Act prevails over that in another statute that prima facie applies. Where the law, either common or statutory, provides for survival of right of action and there is no special time limit then the general limitation act applies. If one turns to our Limitation Act, he will find that it does not mention the death of a claimant. In other words time continues to run as though the claimant were still alive. An obvious example is that of an ordinary debt. On the other hand the Act does provide for the case of the death of a person against whom a claim exists:

Section 5(3)-Where a paraon has a claim against the estate of a deceased person, and the claim was not barred at the date of denth of the person under the proviafons of this Act or any other Act limiting the time within which an action could be brought, an action may be brought to reeover the amount of the clatm (a) within the tine otherwise limited for the bringing of the acton, or (b) within two years from the date of denth, whichever period is the longer.

This certainly shows a generous policy in favour of plaintiffs who bring action against an estate. It also shows, from the words I have put in italics, that it can apply to other statutes that impose a limitation. Yet I have found no case in which the italicized words have been applied. Section 5 (2) quoted earlier says that section 5 does not apply to claims specially limited under other statutes, but surely $5(2)$ should be read subject to $5(3)$.

Returning now to the Trustee Act it is clear that its limitation provision in section 33 prevails over those in the general Act. Thus in an action in negligence for starting a fire, and where the wrongdoer died five months later, an action brought against his estate sixteen months

sxNow The Truntes Act, RB.A. 1965, cap. 36.

sa|I037| A.C.

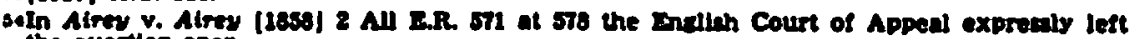
the question open. 
after his death was out of time. ${ }^{3 s}$ It is submitted however that had the Trustee Act not contained its own limitation, the italicized words in section 5 (3) would have applied and the action would have been in time.

The real difficulty arises where section 32 or 33 of the Trustee Act comes into competition with another special provision. Section 131 of The Vehicles Act is a conspicuous example. Let us consider first the case where the wrongdoer dies and the victim brings action against the estate, and then the converse case, where the victim dies and his estate brings action against the wrongdoer. (There is also the case where both have died and the action is between the two estates. This situation is mentioned at the end of this section.)

(1) In the Ontario case of Dressel v. Glaseryt the accident occurred on September 22, 1951. The wrongdoer died on October 16. His administrator was appointed on October 15, 1952 and action was commenced the next day. Needless to say, the defendant relied on the Vehicles Act and the plaintiff on the Trustee Act. In finding for the defendant the Court of Appeal said the Trustee Act "does not have the effect of taking away a defence which the deceased would have had if he had been living at the time of the appointment of the executor or administrator. Thus it does not operate to deprive the executor of the right to set up the defence the deceased would have had by virtue of [sec. 131 of the Vehicles Act]". The judgment adds that the Trustee Act is general legislation and the Vehicles Act is special.

(2) In the Alberte case of Scott v. Thompson"t the Appellate Division had to consider the converse situation. The accident occurred on November 22, 1952 . The victim died on November 27. His executor brought action on November 24, 1953. Again the defendant relied on the Vehicles Act and the plaintiff on the Trustee Act. The Court pointed out that the Trustee Act says the victim's representatives may maintain an action for tort or injuries to the person in the same manner and with the same rights and remedies as the deceased would if living have been entitled to. The reasoning them seems to be that had the victim himself been the plaintiff, his claim would have been barred and that his estate is in no better position.

These two judgments do not give effect to the one-year provisions that the legislature specifically placed in the Trustee Act when it provided that tort actions should survive. It is respectfully submitted that it is only by virtue of the Trustee Act that the action can be brought at all, and that when that legislation is involsed its own limitation period accompanies it. This was the reasoning of Lord J. in a British Columbia case. 38

A similar issue could arise where the representative brings action against a city or a public officer. On the reasoning of Scott v. Thompson, the City Act or Public Officers Protection Act would prevail, to the defendant's benefit.

As to the possibility of a conflict between the Trustee Act and the Fatal Accidents Act, I have been unable to construct one. The 1960

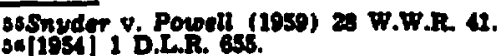

si(10)7 की T.T.R. 20.

susteobel v. MeDonald (1259) 29 W.W.R. 226 
amendment to the latterso puts beyond any doubt the right of the dependants to bring action against the wrongdoer's estate no matter which of the two dies first. It seems clear on the Gentile principle that the Fatal Accidents Act governs, and the fact that the wrongdoer has died, whether before or after the victim, is immaterial.so

The only problem I can imagine in a case of this kind arises entirely within the Trustee Act. Suppose now victim and wrongdoer are both dead, but that they died at different times. In a claim under the Trustee Act, e.g. for loss of expectation of life does section 32 apply or section 33 ? In other words does time run from the victim's death or the wrongdoer's? Of course if the deaths arose out of a car accident then Scott $v$. Thompson says the Trustee Act does not apply anyway. Assuming it to apply, the reasonable rule would seem to be that time would begin to run under the Trustee Act from the death of the one who died first.os

\section{Medical, Dental and Hospital Acts}

The Medical Profession Act says that no physician "is liable to an action for negligence or malpractice ... unless the action is commenced within one year from the date when the professional services complained of terminated".02 Apart from verbal differences the Dental Association Act is the same." The notable feature of these Acts, which are not unique to Alberta, is that time runs from the date when the physician's services relating to the matter of the complaint came to an end.

Usually this is the last day on which the physician attended the plaintiff in connection with the complaint that later becomes the cause of action."

These provisions operate harshly against the plaintiff in a case where the negligence is not manifest for over a year after the patient has ceased to attend. This can occur where an object like a sponge has been left in the patient's body after an operation. In an Alberta case the object was not discovered until five and a half years later. However the plaintiff had consulted the defendant about the pain in her abdomen shortly before the discovery, and he assisted in the removal of the object. McLaurin C.J.T.D. held that the action was in time."s

It will be noted that these provisions extend to malpractice as well as negligence so it is suggested here that they apply where there is an unauthorized operation, usually called "medical assault"."o

The Hospitals Act says that actions against an approved hospital must be commenced within one year after the cause of action arose." I know of no reported case on this section. Where the patient has died after an interval of time, a problem could arise as to whether his

so1860, enp. $\mathbf{2 1 .}$

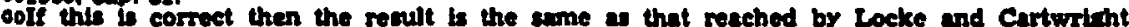
Jj., the only member of the Bupreme court of Candi who sound it necesing io den

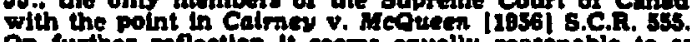

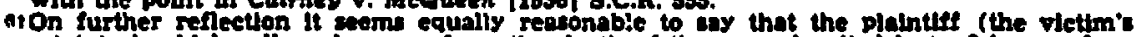
ethte) thould be allowed a year fram the denth of the one who died lat. I know of no ease on the point.

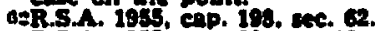

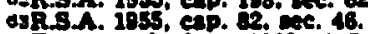

ostowen v. Archer (1003) + O.L.R. 203.

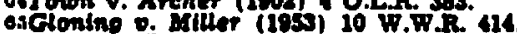

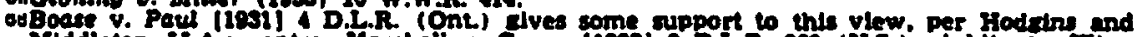

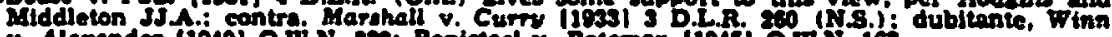

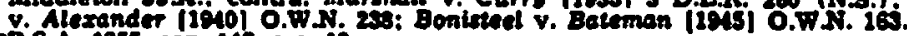

orR.sA. 19s, enp, 147, 6p. ip. 
representative is entitled to one year from the death or whether he is still bound by the Hospitals Act.

One argument, perhaps fanciful, that a hospital (at least a municipal one) might raise is this. A hospital is clearly a public authority and therefore is entitied to the benefit of the Public Officers Protection Act. It is true that Hall, C.J.Q.B. in Saskatchewan has held that hospital legislation is special and prevails over the more general Protection Act, ${ }^{\text {cs }}$ but our Protection Act hes its "notwithstanding" clause, and perhaps a hospital could persuade the court to apply it.

The Calgary Fospital Board Act gives to that Board the benefit of the limitation provision in the City Act, including the requirement of notice.

\section{Amendments, Counterclaims, Third Parties}

A fudge may at any stage of the proceedings allow either party to amend his pleadings. ${ }^{70}$ There is no need here to examine in detail the principles on which the courts exercise their discretion to permit amendments. Generally one can say they do so freely. We are concerned solely with the situation where a plaintiff seeks an amendment that sets up a new cause of action and does so at a time after that new cause of action is barred. The leading case of Weldon v. Neal' holds that such an amendment should not be permitted. The defendant should not be deprived of the benefit of the Statute of Limitations.

Sometimes it is hard to determine whether an amendment in fact sets up a new cause of action. Where the action is for damage to a vehicle and an amendment is propased after the lapse of the statutory period to include a claim for personal injuries, ${ }^{73}$ or loss of employees' services's or where the plaintiff wants to make an allegation of wilful and wanton misconduct" it has been held that all of these set up a new cause of action.

In a number of cases under the Fatal Accidents Act the statement of claim has been defective in not setting out all the facts required to show a cause of action. In Saskatchewan," Manitoba," and Bngland" the Court has taken a strict view and refused to permit an amendment after the statutory period. Our Appellate Division took a more lenient position, where the plaintiff had omitted to state that she brought action as administratrix. ${ }^{70}$ She was allowed to make the amendment.

Saskatchewan has a provision in the Queen's Bench Act ${ }^{30}$ expressly enabling the Court to permit an amendment even though the statutory period has passed, provided the amendment does not involve a change of

ostiecArthe v. Sack. Conesr Comm. (19ss) 27 W.T.R. 162.

enses. eap. 7, exe. 4.

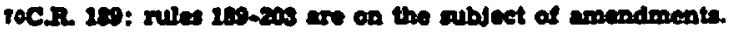

n (196) 10 QRD. 21.

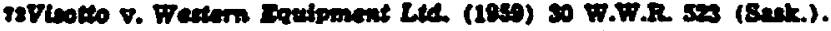

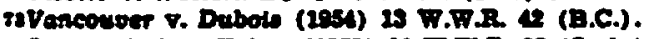

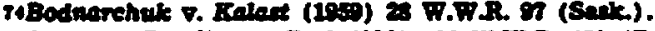

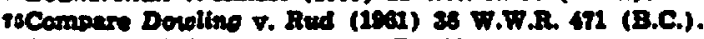

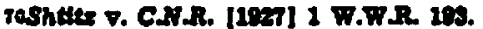

IILast V. Alhworh (1954) 14 W.T.R. 17 .

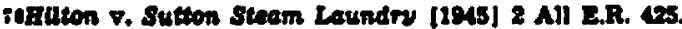

Thullter v. C.P.R. [2003] i W.W.R. 229.

0 R.8.8. 1983, cap. 67, sec. $48(11)$. 
parties other than one caused by death of one of the parties. I have found no comparable provision in Alberta and mention it because it seems worth considering.

The subject of adding parties, whether plaintiff or defendant, can be dealt with here, because it is often treated as a matter of amendment even though the adding of a plaintiff or defendant is really more than an amendment. The rules of court provide for adding parties, ${ }^{n 1}$ but the cases say they should not be added after the limitation period has expired." The most belpful case on the whole subject is one in our Appellate Division, Western Canadian Greyhound Limes v. Pomerleau."s In that case the statement of claim described Alcide Pomerleau as owner and John Pomerleau as driver. After the defence was filed, the plaintiff sought to amend, because, in fact, Alcide was driver and John was owner. By this time the one-year period. laid down by section 131 of the Vehicles Act had passed. The judgment sets out three classes of cases in which an amendment after the statutory period will be refused: (1) where the action is a nullity $a b$ initio, (2) where it is sought to add or substitute plaintiffs and defendants and (3) where it is sought to add a new cause of action. The amendment here was not within any of these classes and did not prejudice the defendant and therefore was allowed. A fortiori an ordinary misnomer may be corrected.

Coming now to counterclaims, the general rule is that a counterchim must be brought before the time for bringing action has expired. One can imagine an accident in which two car drivers are instantly killed. The representative of one brings action under the Fatal Accidents Act against the representative of the other after 11 months and 28 days. The latter may wish to counterclaim under the same Act, but after the twelve months have gone by, it is too late.

In the case of the Vehicles Act, however, there is a special provision (sec. $131(2)$ ) which says that where action is brought for damages "occasioned by a motor vehicle" and a counterclaim is made by a defendant in respect of damages occasioned in the same accident, the lapse of time limited by this Act is no bar to the counterclaim. In Buck v. Kinshella," a defendant, who had counterclaimed, sought to amend the counterclaim to correct an error as to which of the plaintiffs was the driver and which was the passenger. The Appellate Division held that section 131(2) makes it clear that lapse of time is no bar to a counterclaim and hence is not a bar to an amendment thereof. The court can exercise its discretion on the usual principles.

A question that could arise is this. A defendant who counterclaims joins as a defendant to the counterclaim a person who was not a plaintiff in the original action. Does section 131(2) apply so that the person may be so joined after the lapse of a year? The Rules of Courts contemplate that such a person may be added and I see no reason why

me.2. 61, 62.

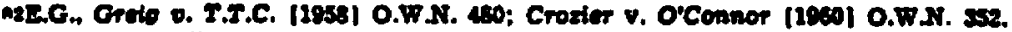

ma (18s5) 15 F.F.R. INe.

as(1953) 85 T.T.R. SPs.

aAC.R. 103. 
the Rules should not be applied here. ${ }^{\text {ss }}$ Whether this result is unjust to the person so added, I have no opinion.

The last major problem has to do with proceedings by a defendant to join some one else as a defendant or third party. The Rules of Court have always provided for both of these, but it will be remembered that third party procedure*o has traditionally been used to enable a defendant to bring into the proceedings someone who is obliged to indemnify him. It could not be used to claim contribution in tort actions for the simple reason that the substantive law did not allow contribution as between co-tortfeasors. It will be remembered too that the courts are reluctant to enforce a new defendant on the plaintiff.

However the Tortfeasors Act of 1936*i provides:

4. (1) There damage is aufiored by any person as a result of a tort ...

(c) any tort-foasor libble in respect of that damage may recover contribution from any other tort-feasor who is or would, if sued, have been liable in respect of the same damage, whether as a joint tort-feasor or otherwies,....

And the Contributory Negligence Act of $1937^{\text {ns }}$ provides:

Sec. 8. "Whenover it appears that a person not alrody party to an action is or may be wholly or partly responsible for the domages elaimed, such person may be added an a party defendant".0

I doubt that this is often done, at least if the plaintiff objects; and in principle it cannot be done after the period of limitation has passed.

However the defendant often takes third party proceedings against someone he alleges to be partly to blame, hoping that the Court will apportion some (if not all) of the fault against that person.

This raises a question. Suppose the third party proceedings are taken after the expiration of the time within which the plaintiff could have sued the third party? Where section 131 of the Vehicles Act applies lapse of time is no bar, and indeed our Appellate Division has heldoo that the defendant may include in the third party proceedings a claim against the third party for the defendant's own damages. Thus he may in effect bring an action against the third party after the year has passed.

In cases to which section 131 does not apply, real difficulty has arisen as to whether third party proceedings can be taken with a view to obtaining contribution where the plaintiff's right of action against the third party has expired. The most likely case is that where the third party is a public officer. Quite possibly, the action was started more than six months after the accident. Fad the public officer been sued in the first place, he would have had a defence. In Cobble v. Mills,"

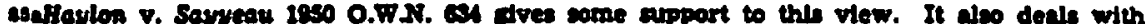
the problem of a counteralain under the Intel Acetdents Act and Truntee Act. The

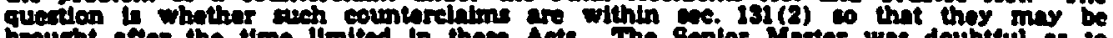

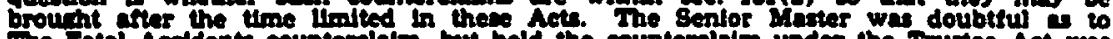
The rotal Aeddent counterelalm, but hold the counierelaim under the Trurtee Act was not with ees. $131(2)$ and was out of time.

acd. $\mathrm{Bl}$.

onNor R.SA. 1045, eAp. 2as.

ANNow R.B.A. 1955, eap. 85.

noCubit v. Forth [194] 2 W.W. I. 12 presertbes the praetlee. It might be nolod that in Ontarlo. Where there to a Contributory Nedirence Aet. but no Tortensor's Act, a defendant who hes been found libble to the plaintles may not brins a subequent ection arainst another for contributlan. Bee Cohwe v. MeCord [194] \& D.L.R. 75s: Rtekroood v. Avime (IOST) o D.IR. (2d) 702 .

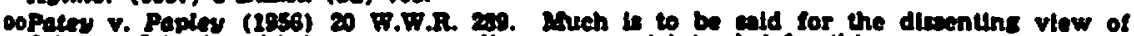
Johrom J.A. that inled parto procending were not intended sor this purpose.

o1Nole 31, mpre. 
Boyd McBride J. held that in these circumstences the defendant was not entitled to have the public officer joined. He adhered to this view in Sargent v. Canadian Coachways, but the Appellate Division upheld the third party notice because there was doubt as to the correctness of the view of Mr. Justice McBride and also doubt as to whether the third party was within the Protection Act.o2

When the case was decided on its merits, the third party was found not to be a public officer, so we do not know what position the Appellate Division would have taken had he been."2

Several years later, the English Court of Appeal held, at least by way of dictum, in Wimpey v. B.O.A.C." that the effect of section 4 (1) (c) of the Tortfeasors Act is that a defendant's action for contribution may be brought after judgment against him has been obtained and that therefore, where a defendant seeks contribution through third party proceedings, time does not run in favour of the third party from the date of the accident, but only from the time the plaintiff obtains judgment against the person seeking contribution. In this view third party proceedings against a public officer are on time even though instituted more than six months after the accident. Since the Wimpey case Parliament has repealed the Public Authorities Protection Act, so the exact question cannot again arise in England, but there may be similar situations where the third party has the benefit of a short period under some other statute."s

If the opinion of the Court of Appeal in Wimpey is accepted in Alberta, it will mean that section 4(1) (c) operates to remove from a third party a defence that a special limitation period appears to have given him. On the other hand, the opposing view, that of Boyd McBride J., seems unfair to the original defendant. He cannot compel the plaintiff to take action against him within six months and yet if the action is brought after that period, then it is too late for the defendant to join the public officer as a third party with a view of obtaining a contribution from him.

\section{Conclusion}

This concludes our survey of the law. Question of limitations arise continually and it is trite to point out that the law should be ascertainable, definite, simple and fair. This account shows that in too many instances our Iaw of limitations does not meet these tests.

It is relevant to note that in Ingland there was after World War II criticism of the Public Authorities Act and of the short period (one year) under the Fatal Accidents Act.on In 1948 the Iord Chancellor appointed a Committee to make recommendations on the subject. The Committee recommended the repeal of the Public Authorities Protection Act and an extension to two years of the period under the Fatal Accidents Act." In 1954 Parliament accepted these recommendations, save that it extended the time under the Fatal Accidents Act to three years." One

22[1949] I W.T.R. 2005 .

istote 49, inpra.

4[19ss] 2 QB. son. [20ss] A.C. 100. The Houre of Lards left the polnt open.

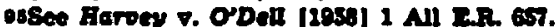

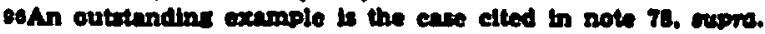

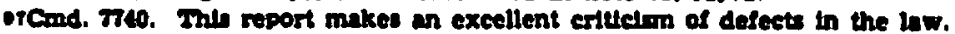

ouktole 11, Eupro. 
must be envious of the present simplicity of the English provisions.

The foregoing survey, it is submitted, warrants the following recommendations. Because of the length of this paper, they are made without elaboration and in full knowledge that there may be differences of opinion on some of them.

Recommendations:

(1) Repeal of the Public Officers Protection Act and Rule 651 which repeats the main provision of the Act.

(2) Repeal of the requirement of notice before action in claims under the City Act except in cases of failure to repair streets (including snow and ice)."0

(3) Repeal of the special periods in the municipal acts and the Vehicles Act, so that the general Act will apply.

(4) Enalargment of the period under the Fatal Accidents Act to two years.

(5) If recommendations 2 to 4 inclusive are not practicable, then at least all periods for tort should be set out in the Limitations Act and special provisions should be included to make it clear which provision prevails in a given case. (This last would be a formidable task for the draftsman.) 